\title{
KOMPETENCJA SKŁADNIOWA I JEJ NIEDOSTATKI W POLSZCZYŹNIE MÓWIONEJ CUDZOZIEMCÓW UCZĄCYCH SIE JĘZYKA POLSKIEGO JAKO OBCEGO
}

Słowa kluczowe: nauczanie JPJO, kompetencja składniowa, błąd składniowy, język mówiony

Streszczenie. Artykuł dotyczy kompetencji składniowej oraz jej niedostatków w polszczyźnie mówionej cudzoziemców. Autorka przedstawia i omawia pod względem poprawności składniowej spontaniczne wypowiedzi studentów z Angoli, zebrane podczas obserwacji lekcji języka polskiego jako obcego w Studium Języka Polskiego dla Cudzoziemców UŁ. Zestawienie wypowiedzi poprawnych z błędnymi pozwoliło zaobserwować, które zagadnienia składniowe nie sprawiały cudzoziemcom trudności, a które były dla nich miejscem trudnym w polskiej składni.

W czasie lekcji języka polskiego uczący się tworzą rozmaite wypowiedzi. Część z nich zawiera uchybienia pod względem składniowym. W artykule zajmę się zarówno kompetencją składniową, jak i jej niedostatkami, a więc sklasyfikuję poszczególne błędy syntaktyczne.

Przedstawione $\mathrm{w}$ artykule wypowiedzi cudzoziemców zostały zebrane podczas obserwacji zajęć w Studium Języka Polskiego dla Cudzoziemców UŁ w grupie politechnicznej ${ }^{2}$. Tworzyli ją studenci z Republiki Angoli, którzy przygotowywali się do studiów magisterskich i doktoranckich na Akademii Morskiej w Gdyni. Po ich ukończeniu wszyscy będą wykładowcami na Akademii Rybołówstwa i Nauk o Morzu w Namibe w Republice Angoli. Wiek słuchaczy to 23-38 lat. Język ojczysty uczących się to język portugalski. Żadna osoba nie miała wcześniej kontaktu z językiem polskim. W momencie rozpoczęcia przeze mnie obserwacji poziom grupy określiłam jako poziom progowy (B1).

\footnotetext{
${ }^{1}$ wojtczak.edyta@gmail.com, Uniwersytet Lódzki, Katedra Lingwistyki Stosowanej i Kulturowej, Wydział Filologiczny, ul. Pomorska171/173, 90-236 Łódź.

${ }^{2}$ Korpus wypowiedzi pochodzi z mojej pracy magisterskiej Rola składni w nauczaniu języka polskiego jako obcego, pisanej pod kierunkiem prof. dr hab. Grażyny Zarzyckiej w Katedrze Lingwistyki Stosowanej i Kulturowej UŁ.
} 
Wśród opinii lektorów języka polskiego ${ }^{3}$ na temat składni można znaleźć takie, które mówią o niej jako o istotnym zagadnieniu gramatycznym na lektoratach języka polskiego: „Składnia to podstawowe zagadnienie w nauczaniu języka polskiego jako obcego. Bez poszczególnych relacji między wyrazami w zdaniu, uczący się nie są w stanie zbudować składniowych całości”. Inna lektorka zapytana o rolę składni odpowiedziała, że: ,jest ona bardzo duża. Uważam, że efekty nauczania są dużo lepsze, gdy studenci (zamiast pojedynczych słów, np. zawierać + biernik) opanowują konstrukcje/struktury składniowe, np. coś (mianownik) zawiera coś (biernik) i konkretne zdania. Konstrukcje składniowe tworzą stały „szkielet” języka, na który nakłada się odpowiednie słowa”. Wśród opinii pojawiły się również takie, które zwracały jedynie uwagę na pomocniczą funkcję składni: „ Polszczyzna, której użytkownicy chętnie stosują szyk przestawny (możliwy dzięki fleksyjnej naturze języka) nie wymaga stosowania stałych schematów składniowych - jak to jest w językach pozycyjnych. Nauczanie składni ma funkcję pomocniczą, przy nauczaniu sprawności mówienia i pisania”. Trudno w pełni zgodzić się z tą opinią, gdyż język polski również wymaga „organizacji słów w zdania według określonych kategorii, elementów, klas, struktur, mechanizmów oraz związków" (Europejski system... 2003, s. 104), czym właśnie jest składnia. Kompetencja składniowa to zatem znajomość i umiejętność stosowania tego zestawu reguł przy tworzeniu konstrukcji składniowych. Syntaktyka nie pozostaje więc bez znaczenia. Dlatego jest to zagadnienie, któremu warto poświęcić uwagę.

\section{SKLADNIA ZGODY}

Składnia zgody (łac. kongruencja) to „zależność form wyrazu określającego polegająca na ich dostosowywaniu za każdym razem do formy określanego rzeczownika pod względem przypadka, liczby i rodzaju" (Jodłowski 1976, s. 63-64).

Ze składnią podmiotu i orzeczenia czasownikowego studenci nie mieli większych problemów (Pan pewnie dobrze mówi po angielsku; Kobiety w Polsce wolq sprzątać niż gotować). Błędy pojawiały się incydentalnie (Maria SkłodowskaCurie zajmowat się badaniem fizyka i chemia zamiast: Maria Skłodowska-Curie zajmowała się badaniem fizyki i chemii).

Więcej problemów sprawiła studentom składnia zgody w zakresie przydawek przymiotnych, choć pojawiały się wypowiedzi poprawne (Przepraszam Pana, to moja wina; Jakie sa obie rodziny?). Błędy dotyczące przydawki przymiotnej polegały na wyborze niewłaściwego:

\footnotetext{
${ }^{3}$ Opinie zebrałam wśród lektorów z ponadtrzydziestoletnim stażem.
} 
a) rodzaju gramatycznego zarówno w zdaniach pojedynczych (Obserwujemy niepokojacy zjawisko $w$ rzekach $i$ wodach ${ }^{4}$ zamiast: Obserwujemy niepokojące zjawisko w rzekach i wodach; Mój ołówek umiera. Muszę kupić nowe zamiast: Mój ołówek kończy się. Muszę kupić nowy), jak i w zdaniach złożonych (Chciałabym maszynę, który zmienia fryzurę zamiast: Chciałabym maszynę, która zmienia fryzurę; Jak nazywa osoba, który wymyśla języka polskiego? zamiast: Jak nazywa się osoba, która wymyśla język polski?);

b) liczby (Zgubiłem moja teksty zamiast: Zgubiłem moje teksty; Istnieja różny typy reaktory jądrowe zamiast: Istnieją różne typy reaktorów jądrowych);

c) przypadka (Rodzina jest blisko, pogoda, który lubię zamiast: Rodzina jest blisko, pogoda, którą lubię; Lech Watęsa jest symbol wyzwolona od komunizmu Polski zamiast: Lech Wałęsa jest symbolem wyzwolonej od komunizmu Polski). Pojawiły się również uchybienia w składni przydawki liczebnikowej (Prosze powtórzyć pierwsze przykład zamiast: Proszę powtórzyć pierwszy przykład).

\section{SKLADNIA RZĄDU}

Składnia rządu (łac. rekcja) polega na tym, że: „wyraz określany wymaga jednej szczególnej (tej, a nie innej) formy wyrazu określającego, niezależnej od zmian, jakim ulega sam" (Jodłowski 1976, s. 64).

\subsection{REKCJA BEZPRZYIMKOWA}

Ten rodzaj rekcji dotyczy dopełnień oraz przydawek przypadkowych. W swoich wypowiedziach studenci popełniali wiele błędów dotyczących rekcji, choć nie zabrakło wypowiedzi poprawnych.

W wypowiedziach dotyczących dopełnienia studenci stosowali prawidłową rekcję biernikową (On rozmawiat cała lekcję; Jeżeli człowiek naruszy równowage to jest niedobrze $e^{6}$. W zdaniach niepoprawnych błąd najczęściej polegał na użyciu mianownika w miejsce biernika (Kopnać piłka nożna zamiast: Kopnąć piłkę nożną; Osoba, która ma kot to czarownica zamiast: Osoba, która ma kota to czarownica; My mamy też taka tradycja, żeby gotować mata świnia zamiast: My mamy też taką tradycję, żeby gotować małą świnię), choć zdarzało się również użycie innego przypadka (Zgubilem kartce zamiast: Zgubiłem kartkę).

\footnotetext{
${ }^{4}$ Fragment wypowiedzi dotyczącej kwaśnych deszczów.

${ }^{5}$ Odpowiedź na pytanie: Jakie zalety ma Angola?

${ }^{6} \mathrm{O}$ ingerencji człowieka w środowisko naturalne.
} 
Cudzoziemcy budowali poprawne wypowiedzi z rekcją narzędnikową (Najpierw zajmowat się pisaniem reportaży ${ }^{\top}$ ), ale nie zabrakło również wypowiedzi błędnych (Ona była pierwsza kobieta, który dwa razy byt premiony ${ }^{8}$ Nagrody Nobla zamiast: Ona była pierwszą kobietą, która dwa razy była nagrodzona Nagrodą Nobla; Możemy płacić przez kartę zamiast Możemy płacić karta).

Wśród wypowiedzi z rekcją dopełniaczową pojawiły się wypowiedzi poprawne (Ja uczę się języka polskiego; Potrzebuję przykładu; Macie dużo słów ${ }^{10}$, Nie mam kartki, Tutaj nie ma negacji). Jednak w większości przypadków rekcja ta wiązała się z popełnianiem błędów dotyczących:

a) rekcji po czasowniku (Kiedy chcemy zatożyć firme myśle, że najpierw potrzebujemy kapitat, a potem ludzie, który pracuje, a potem dobry pomyst. Nie! Najpierw dobry pomys $t^{11}$ zamiast: Kiedy chcemy założyć firmę myślę, że najpierw potrzebujemy kapitału, a potem ludzi, którzy pracują, a potem dobrego pomysłu. Nie! Najpierw dobry pomysł; Łaczyć dwa ciała - metale - za pomoca wysoka temperatura zamiast: Łączyć dwa ciała - metale - za pomocą wysokiej temperatury);

b) rekcji po liczebniku nieokreślonym - dopełniacz cząstkowy (Ma dużo zalety! $!^{12}$ zamiast: Ma dużo zalet!; Dzisiaj mamy dużo ćwiczenie zamiast: Dzisiaj mamy dużo ćwiczeń);

c) rekcji liczebników (Wybrałem dwóch mężczyźni. Pierwszy Władysław Reymont, drugi Lech Watęsa ${ }^{13}$ zamiast: Wybrałem dwóch mężczyzn. Pierwszy Władysław Reymont, drugi Lech Wałęsa);

d) rekcji po zaprzeczonym czasowniku być w formie osobowej i negacji biernika (Jeżeli nie ma energia, nic nie pracuje ${ }^{14}$ zamiast: Jeżeli nie ma energii, nic nie działa; Kiedy kobieta jest wymagająca i uparta nie będzie miała mąz. ${ }^{15} \rightarrow$ Kiedy kobieta jest wymagająca i uparta, nie będzie miała męża).

Studenci tworzyli również wypowiedzi z poprawną rekcją w zakresie przydawki dopełniaczowej. (Klient biura; To jest konsekwencja reakcji jądrowej). Nie zabrakło jednak wypowiedzi błędnych (Tablet to dziecko komputer zamiast: Tablet to dziecko komputera; Kiedy będzie prezentacja twoja praca? ${ }^{16}$ zamiast: Kiedy będzie prezentacja twojej pracy?)

\footnotetext{
${ }^{7}$ O Henryku Sienkiewiczu.

${ }^{8}$ Prêmio (port.) nagrodzony.

${ }^{9}$ Odpowiedź na pytanie: Jak płacimy za zakupy zrobione w Internecie?

${ }^{10} \mathrm{O}$ języku polskim.

${ }^{11}$ Odpowiedź na pytanie: Co musimy mieć, żeby założyć firmę?

${ }^{12}$ Odpowiedź na pytanie: Jakie zalety ma Angola?

${ }^{13}$ Odpowiedź na pytanie: O którym polskim nobliście chciałby pan opowiedzieć?

${ }^{14}$ Odpowiedź na pytanie: Czy energia elektryczna jest ważna?

${ }^{15}$ Uwaga studenta na temat cech kobiety nienadającej się na żonę.

${ }^{16}$ Pytanie dotyczyło obrony mojej pracy magisterskiej.
} 


\subsection{REKCJA PRZYIMKOWA}

Rekcja przyimkowa dotyczy „dystrybucji przypadków rzeczowników w stosunku do poszczególnych przyimków" (Jodłowski 1976, s. 64). Przyimki te wraz z różnymi wyrazami tworzą konstrukcje syntaktyczne.

Studenci mieli duży problem z tym typem rekcji. Wypowiedzi zawierające błąd w rekcji przyimkowej były liczniejsze niż wypowiedzi bezbłędne. Uczący się tworzyli poprawne zdania z przyimkami ze znaczeniem lokatywnym (Kto mieszka w Piotrkowie?; Wyraz ,,zmieszać" możemy używać w chemii?), związanymi z przekazem informacji (Uczytam sie, kiedy rozmawiałam o mieszkaniu ${ }^{17}$ ) oraz wskazującymi na charakterystyczną cechę - składnik, dodatek (Lubię kawę z mlekiem).

Błędy w rekcji dotyczyły przyimków tworzących wyrażenie przyimkowe $\mathrm{z}$ rzeczownikiem $\mathrm{w}$ :

a) dopełniaczu:

- bez (Bez pieniadze nie ma plany ${ }^{18}$ zamiast: Bez pieniędzy nie ma planów);

- dla (Ten czasownik możemy używać dla osoba też? ${ }^{19}$ zamiast: Ten czasownik możemy też używać w odniesieniu do osoby?);

- od i do ze znaczeniem temporalnym (Lech Watęsa byt prezydentem w Polsce od tysiąc dziewięćset dziewięćdziesiat jeden do tysiąc dziewięćset dziewięćdziesiat pięć zamiast: Lech Wałęsa był prezydentem w Polsce od tysiąc dziewięćset dziewięćdziesiatego pierwszego do tysiąc dziewięćset dziewięćdziesiatego piatego;

- $u$ (W sobotę byłam u koleżanka zamiast: W sobotę byłam u koleżanki);

b) narzędniku:

- pod - ze znaczeniem lokatywnym (Skaty to sa bardzo trudne znaleźć, bo one sa pod ziemię zamiast: Skały trudno znaleźć, bo one są pod ziemią);

- $z$ - przyimek wskazujący na osobę towarzyszącą (Może być też: ile osób mieszka z Pawła ${ }^{20}$ zamiast: Może być też: ile osób mieszka z Pawłem; Ja ogladałam z córka. Ona lepiej zna ${ }^{21}$ zamiast: Ja oglądałam z córką. Ona lepiej ją zna);

c) miejscowniku:

- $n a-$ ze znaczeniem lokatywnym (Jeżeli olej zostanie na dno morza, to jest bardzo niebezpieczne zamiast: Jeżeli olej zostanie na dnie morza, to jest bardzo niebezpieczne; Na ziem mamy dużo śmieci zamiast: Na ziemi mamy dużo śmieci) oraz gdy wskazuje zarówno na czas, jak i na miejsce czynności - gdzie? kiedy? (Co będzie na egzaminu zamiast: Co będzie na egzaminie?);

${ }^{17}$ Odpowiedź na pytanie: Skąd pani zna to stowo?

${ }^{18}$ Odpowiedź na pytanie: Jakie plany na weekend?

${ }^{19}$ Pytanie dotyczy czasownika uwielbiać.

${ }^{20}$ Studenci musieli pytać się wzajemnie o informacje zawarte w przeczytanym tekście. Jedna osoba zapytała o możliwość zadania innego pytania do przeczytanego przez studentów tekstu.

${ }^{21}$ Odpowiedź na pytanie: Zna pani tę bajkę? 
- $o$ - przyimek wskazujący na temat jakiegoś przekazu informacji (Tekst mówi o reaktor zamiast: Tekst mówi o reaktorze; Może być o osoba, która biega? ${ }^{22}$ zamiast: Może być o osobie, która biega?);

- $w$ - przyimek wskazujący na położenie - gdzie? (Mam alarm $w$ samochód zamiast: Mam alarm w samochodzie) oraz wskazującym na grupę społeczną, środowisko lub instytucję (Kompost może być używany w rolnictwo zamiast: Kompost może być używany w rolnictwie).

Przyimki: pod, $n a, o$ oraz $w$ łączą się również z biernikiem, a przyimek $z$ z dopelniaczem (Uniwersalny stownik..., 2003). Jednak w innych znaczeniach niż te występujące w przytoczonych wypowiedziach cudzoziemców.

Cudzoziemcy tworzyli również wypowiedzi, w których używali niewłaściwego przyimka, co ilustrują poniższe przykłady:

- Nic specjalnego. Ale w piatek bytem do lekarza, ale lekarz mówi, że tutaj ma specjalistę dla cudzoziemców ${ }^{23}$ zamiast: Nic specjalnego. Ale w piątek byłem u lekarza i on powiedział, że tutaj jest specjalista dla cudzoziemców.

Przyimek $d o$ wskazuje na cel ruchu przestrzennego. Natomiast przyimek $u$ na osobę będącą właścicielem lub użytkownikiem miejsca. Student nie powiedział: poszedtem do lekarza, ale bytem u lekarza, co nie jest związane z ruchem przestrzennym

- Jedna maszyna specjalna dla spawania ${ }^{24}$ zamiast: Jedna specjalna maszyna do spawania.

Użyty przyimek dla wskazuje na cel działania. Właściwym przyimkiem jest do, który wskazuje na przeznaczenie. Maszyna jest przeznaczona do spawania, nie ma tu mowy o czynności będącej celem działania.

- Było duzy ruch. Kucharze gotowat specjalne potrawy. Ludzie byli w sklepie. Kupowali piękne stroje dla imprezy. ${ }^{25}$ zamiast: Był duży ruch. Kucharze gotowali specjalne potrawy. Ludzie byli w sklepie. Kupowali piękne stroje na imprezę.

W powyższym przykładzie jest mowa o celu działania. Mimo to przyimek dla nie jest właściwy. Właściwy jest $n a$, który też wskazuje na cel. W tym przypadku należy wziąć pod uwagę uzus językowy.

W swoich wypowiedziach studenci często pomijali również przyimki (Żelazo nie odporne korozja zamiast: Żelazo nie jest odporne na korozję; Możemy powiedzieć przepis też ciastko? ${ }^{26}$ zamiast: Możemy też powiedzieć przepis na ciastko?; Rachunek energia jest bardzo droga zamiast: Rachunek za energię jest bardzo

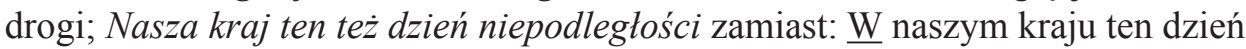
to też dzień niepodległości).

\footnotetext{
${ }^{22}$ Pytanie dotyczy czasownika wytrzymaty.

${ }^{23}$ Odpowiedź na pytanie: Co pan robit w weekend?

${ }^{24}$ Odpowiedź na pytanie: Co jest potrzebne do spawania?

${ }^{25} \mathrm{O}$ jednej ze współczesnych afrykańskich bajek.

${ }^{26}$ Pytanie dotyczy słowa przepis. Student podał przykładowe zdanie.
} 


\section{ORZECZENIE SLOWNO-IMIENNE}

Ten typ orzeczenia składa się ze słowa posiłkowego, które włącza podmiot w zakres orzeczenia oraz imiennego łącznika (Jodłowski 1976, s. 74).

Studenci potrafili tworzyć wypowiedzi z orzeczeniem w mianowniku (Wy jesteście bardzo wymagajacy, a my nie mówimy po polsku; Dulce jest uparta $i$ wy$\underline{\text { magajaca }}^{27}$ ). Natomiast często popełniali błędy polegające na stosowaniu mianownika po słowie posiłkowym być, gdy orzecznik wyrażony jest rzeczownikiem (Ona jest polska poetka $i$ eseistka ${ }^{28}$ zamiast: Ona jest polską poetką i eseistką; Ryba jest najważniejsza potrawa ${ }^{29}$ zamiast: Ryba jest najważniejszą potrawa; $L a$ ser jest urzadzenie wytwarzajace potężne wiazka promieniowanie zamiast: Laser jest urządzeniem wytwarzającym potężną wiązkę promieniowania). Mimo wielu błędnych wypowiedzi pojawiały się również poprawne (Lech Watęsa byt prezydentem Polski; Pani jest nauczycielką ${ }^{30}$ ).

Błędy dotyczące łącznika polegały na jego pomijaniu (Żelazo nie odporne korozja zamiast: Żelazo nie jest odporne na korozję; Naprawdę myślatem, że polon $\mathrm{kraj}^{31}$ zamiast: Naprawdę myślałem, że polon to kraj).

\section{ZDANIA ZLOŻONE}

Cudzoziemcy potrafili budować zdania złożone (Ja pytam, bo nie wiem, czy tak może być; Nie rozumiem dobrze, kiedy używać gerundium). Problemy dotyczące tego typu zdań dotyczyły doboru właściwego spójnika (Co musi mieć jako podstawa i musimy wyrzucać, a co musimy mieć, że nie wyrzucamy? zamiast: Co musi mieć wyraz jako podstawę, że musimy wyrzucić literę, a co musi mieć, że nie wyrzucamy?) lub jego pominięcia (Tutaj mówit potrzebuje passaporte ${ }^{32}$ jest koniec $^{33}$ zamiast: Tutaj mówił, że potrzebuje paszportu, bo jest nieważny).

\section{SZYK}

Język polski nie jest językiem pozycyjnym. Oznacza to, że, „że szyk nie pełni zasadniczo funkcji gramatycznych, a więc jest dość swobodny. Komponując wypowiedzenia polskie, respektujemy jednak pewne zasady porządku linearnego" (Dąbrowska, Pasieka 2004, s. 229). Jest to więc szyk swobodny, ale nie dowol-

\footnotetext{
${ }^{27} \mathrm{O}$ jednej z koleżanek.

${ }^{28}$ O Wisławie Szymborskiej.

${ }^{29} \mathrm{O}$ potrawie wigilijnej.

${ }^{30}$ Pytanie do mnie.

${ }^{31}$ O Polonie (pierwiastku chemicznym).

${ }^{32}$ Passaporte, czyli paszport.

${ }^{33}$ Odpowiedź na pytanie: Gdzie jest pan Eduardo?
} 
ny. Analiza szyku polszczyzny mówionej może przysparzać trudności, ponieważ „nie zawsze naruszenie zgodnych z uzusem zasad szyku wyrazów w grupie syntaktycznej lub wypowiedzeniu prowadzi do naruszenia komunikacji. Może ono prowadzić do sytuacji, w której dana wypowiedź przestaje być neutralna [...]" (Dąbrowska, Pasieka 2004, s. 229). Przedstawione poniżej wypowiedzi poddałam analizie biorąc pod uwagę najbardziej naturalny układ składników w wypowiedzeniu jakim jest: podmiot - orzeczenie - dopełnienie (Dąbrowska, Pasieka 2004, s. 235).

Wśród wypowiedzi cudzoziemców zdarzały się takie, w których dochodziło do zmiany kolejności podmiotu, orzeczenia i dopełnienia (Poniedziałek dla nas to jest trudne zamiast: Poniedziałek jest dla nas trudny).

Studenci budowali zdania, w których umieszczali podmiot w pozycji finalnej zamiast inicjalnej (Może być na inne miejsce „przez”? zamiast: „Przez” może być na innym miejscu?)

Dość często cudzoziemcy mieli problem z szykiem podmiotu, orzeczenia i okolicznika. Budowali wypowiedzi o schemacie: podmiot - okolicznik - orzeczenie. W takim zdaniu pozycja okolicznika powoduje „rozbicie linearnej przyległości podmiotu i orzeczenia" (Stasieczek-Górna 2011, s. 298), co stanowi błąd (To w nasze głowy nie wchodzi $i^{34}$ zamiast: To nie wchodzi do naszych głów).

Zdarzały się wypowiedzi, w których okolicznik czasu występował w postpozycji do podmiotu i orzeczenia (Miałem watpliwości, dlatego zapytatem zawsze paniq Edytę $e^{35}$ zamiast: Miałem wątpliwości, dlatego zawsze pytałem panią Edytę). Czasami w zdaniu zawierającym kilka tego typu okoliczników dochodziło do zaburzenia szyku, polegającym na tym, że jeden z nich umieszczano w pozycji przed orzeczeniem, a pozostałe po nim ( $W$ piatek ja byłam na zakupach cały czas po lekcji zamiast: W piątek po lekcji cały czas byłam na zakupach).

Występowały również wypowiedzi, w których nie umieszczano okolicznika jak najbliżej określanego wyrazu (W jakich sytuacjach ja mogę używać ", upadać" dokładnie? zamiast: W jakich dokładnie sytuacjach mogę używać „upadać”?).

W języku polskim zdarzają się sytuacje, w których podmiot powinien znajdować się w postpozycji do orzeczenia. Wynika to z uzusu językowego. Dotyczy to na przykład podmiotu wyrażonego pronominalizowanym rzeczownikiem pan/pani (Pan pamięta, kiedy umierat Mendelejew? zamiast: Pamięta pan, kiedy umarł Mendelejew?).

Cudzoziemcy mieli również problem z szykiem przydawek (przymiotnych i rzeczownych). Właściwym dla języka polskiego szykiem jest prepozycja przydawki charakteryzującej oraz postpozycja przydawki gatunkującej względem wyrazu określanego (Dąbrowska, Pasieka 2004, s. 231).

\footnotetext{
${ }^{34}$ Odpowiedź na pytanie: Rozumieja państwo?

${ }^{35}$ Odpowiedź na pytanie: Dlaczego pan caty czas mówi coś do pani Edyty?
} 
Studenci umieszczali przydawkę charakteryzującą w postpozycji do określanego wyrazu (Jedna maszyna specjalna dla spawania zamiast: Jedna specjalna maszyna do spawania; Kiedy chcemy rzecz konkretna $^{36}$ zamiast: Kiedy chcemy konkretną rzecz) lub przydawkę gatunkującą w prepozycji do określanego wyrazu (Gdzie mieszka Pawła rodzina? zamiast: Gdzie mieszka rodzina Pawła?).

Negacja w języku polskim składa się z modulantu nie i wyrazu modyfikowanego. Modulant jako wyraz niesamodzielny składniowo oraz jako wyraz tylko semantycznie związany z członem modyfikowanym, musi przez szyk zaznaczyć przynależność do wyrazu modyfikowanego (Zawilska 1997, s. 26). Miejsce modulantu to prepozycja $\mathrm{w}$ stosunku do wyrazu modyfikowanego. $\mathrm{Z}$ tym zagadnieniem studenci radzili sobie dość dobrze (Nie wiem co to jest ,zatruty”, Niestety nie znalazłem). Sporadycznie umieszczali modulant nie w postpozycji do wyrazu modyfikowanego (Żelazo to jest nie minerat? zamiast: Żelazo to nie jest minerał?).

Charakterystyczna dla języka polskiego jest negacja wielokrotna, na którą, oprócz modulantu nie i wyrazu modyfikowanego, składa się element właściwy tego typu zdaniom zaprzeczonym (np. zaimek nic, przysłówki nigdy, nigdzie). Oczywiście między tymi członami mogą znaleźć się inne składniki zdania, np.: Nic strasznego się nie stało (Uniwersalny stownik..., 2003). W wypowiedziach studentów zdarzały się błędy dotyczące szyku negacji podwójnej (Nie dać nic zamiast: Nic nie dać).

Studenci nie mieli większych problemów z szykiem innych modulantów (,Prać” tylko ubrania?; Nie tylko człowiek wycina lasy. Jeśli Pan Bóg chce to téz wycina).

Wśród wypowiedzi poprawnych można znaleźć przykład właściwego szyku zaimka osobowego (Możesz mi pomagać?), który powinien być umiejscowiony ,jak najbliżej nadrzędnego czasownika, który go poprzedza w ciągu linearnym” (Gębka-Wolak 2010, s. 76).

\section{KONSTRUKCJE DYSMORFICZNE}

Konstrukcja dysmorficzna to taka konstrukcja, która jest zrozumiała, lecz jej forma budzi wiele zastrzeżeń u rodzimych użytkowników języka. Jest to „sekwencja słów pełna usterek morfologicznych, składniowych, semantycznych, czasem logicznych, w której trzeba w procesie odbioru wydobyć poszczególne informacje i złożyć je na nowo" (Dąbrowska 2012, s. 83). Cudzoziemcy budowali tego typu konstrukcje. Poniżej omówię kilka z nich:

\footnotetext{
${ }^{36}$ Odpowiedź na pytanie: Co to znaczy „żądać”, ,domagać się”?
} 
Osoba, który jest zdrowy niemożliwe używać? ${ }^{37}$

Zamiast: Nie można używać „działać” w odniesieniu do osoby, która jest zdrowa?

Dla osiągnięcia akceptowalnej formy zdania, należy przebudować je w taki sposób, aby została wyodrębniona część nadrzędna (Niemożliwe jest używać „,działać” o osobie) i podrzędna (która jest zdrowa) zdania złożonego. W części wypowiedzenia: osoba, który została naruszona składnia zgody (użyto rodzaju męskiego zamiast żeńskiego).

Człowiek naturalne miejsce on przenieść surowce, że on może budować stolice i co on potrzebuje na życie.

Zamiast: Człowiek czerpie surowce ze środowiska naturalnego i on może budować stolice, i to czego potrzebuje do życia.

Jest to zdanie współrzędnie złożone. Zastosowano więc niewłaściwy spójnik że (właściwy zdaniom podrzędnym) zamiast $i$ (występującego w zdaniach łącznych). Część zdania: czlowiek naturalne miejsce on przenieść surowce zawiera błędy leksykalne: przenieść zamiast czerpać oraz naturalne miejsce (również błąd w składni rządu przydawki dopełniaczowej) zamiast środowisko naturalne. Po czasowniku czerpać należy zastosować biernik (surowce). Następnie powinien wystąpić okolicznik (ze środowiska naturalnego). W trzeciej części zdania została zaburzona rekcja bezprzyimkowa (potrzebować + dopełniacz). Zaimek on jest zbędny, ponieważ subiekt konotowany jest końcówką fleksyjną czasownika. Ostatni błąd to użycie niewłaściwego przyimka na zamiast $d o$.

Alfreda Nobla myślę, że swojego wynalazku będzie tylko dla budowy, ale niestety nie byto tak, bo ludzie używaja też dla wojny.

Zamiast: Alfred Nobel myślał, że jego wynalazek będzie wykorzystywany tylko do budowy, ale niestety nie było tak, bo ludzie używają go też podczas wojny.

W pierwszej części zdania złożonego zastosowano dopełniaczową (Alfreda Nobla) zamiast mianownikową formę podmiotu. Została zaburzona również składnia zgody między podmiotem a orzeczeniem (Alfreda Nobla myśle zamiast Alfred Nobel myśla ${ }^{38}$ ). W drugiej części zdania wystąpił błąd leksykalny polegający na użyciu przymiotnika swój zamiast zaimka jego. Niewłaściwa jest również forma podmiotu - dopełniacz zamiast mianownika. Następnym błędem jest użycie niewłaściwego przyimka (dla zamiast $d o$ ). W trzeciej części zdania zabrakło zaimka go oraz użyto niewłaściwego przyimka (dla zamiast podczas).

\footnotetext{
${ }^{37} \mathrm{O}$ czasowniku działać.

${ }^{38}$ Błędny jest również czas użytego czasownika.
} 


\section{PODSUMOWANIE}

Studenci wykazali się kompetencją składniową w zakresie związku zgody między podmiotem a orzeczeniem. Nieco więcej problemów przysporzyła im składnia w zakresie przydawek przymiotnych. Obok wypowiedzi poprawnych pojawiały się błędne. Polegały one na wyborze niewłaściwego rodzaju, liczby lub przypadka przydawki.

Składnia rządu sprawiała więcej problemów. W rekcji bezprzyimkowej studenci stosowali właściwą formę dopełnienia w bierniku. Jeśli pojawiały się błędy, to najczęściej polegały one na użyciu mianownika. Wśród rekcji narzędnikowej i dopełniaczowej pojawiało się więcej błędów. Zwłaszcza ta druga przysporzyła trudności. Dotyczyła ona rekcji po czasowniku, czasowniku zaprzeczonym i liczebniku nieokreślonym oraz rekcji liczebników głównych. Błędy (choć ich liczba nie była duża) pojawiały się również w przypadku rekcji dotyczącej przydawki dopełniaczowej. Rekcja przyimkowa okazała się bardzo trudna dla cudzoziemców. Wypowiedzi błędnych było dużo więcej niż poprawnych. Dodatkowo uczący się stosowali niewłaściwy przyimek lub w ogóle go pomijali.

Studenci tworzyli poprawne wypowiedzi z orzeczeniem słowno-imiennym, gdy orzecznik występował w mianowniku. Czasami nie stosowali narzędnikowej formy orzecznika oraz pomijali łącznik.

Cudzoziemcy nie mieli większych problemów z budowaniem zdań złożonych. Jeśli pojawiał się błąd, to polegał on na wyborze niewłaściwego spójnika lub jego pominięciu.

Szyk okazał się trudnym zagadnieniem. Zdarzały się wypowiedzi z błędnym szykiem podmiotu, orzeczenia, dopełnienia, okolicznika oraz przydawki gatunkującej i charakteryzującej. Studenci nie mieli większych problemów z szykiem negacji, choć pojawiały się błędy przy negacji podwójnej. Pojawiały się również konstrukcje dysmorficzne, choć nie były one liczne.

Z przeprowadzonych przeze mnie badań wynika, że składnia jest zagadnieniem, które przysparza trudności cudzoziemcom uczącym się języka polskiego jako obcego. Analiza języka mówionego, pozwoliła zaobserwować, w jaki sposób obcokrajowcy stosują poznane wcześniej reguły organizacji słów w zdania w swoich spontanicznych wypowiedziach. Jest to istotne przy badaniu kompetencji składniowej, ponieważ ważna jest nie tylko znajomość zestawu reguł przy tworzeniu konstrukcji syntaktycznych, ale również umiejętność ich stosowania, co najwyraźniej widać podczas swobodnych wypowiedzi.

Przykłady niedostatków kompetencji składniowej okazały się dość liczne. W sposób znaczący przeważały nad wypowiedziami poprawnymi. Stąd wniosek, że cudzoziemcy z badanej grupy nie osiągnęli w pełni kompetencji składniowej właściwej poziomowi progowemu. Wspomniane niedostatki nie wpływały zna- 
cząco na proces komunikacji, ponieważ popełniane błędy nie uniemożliwiały zrozumienia mówiącego.

Omówione przeze mnie przykładowe wypowiedzi uczących się języka polskiego jako obcego przedstawiają miejsca trudne w polskiej składni dla badanej grupy cudzoziemców, co może okazać się pomocne lektorom uczącym języka polskiego oraz być punktem wyjścia do dalszych badań nad syntaktyką w polszczyźnie mówionej.

\section{BIBLIOGRAFIA}

Dąbrowska A., Pasieka M., 2004, Szyk wyrazów i jego zaburzenia spowodowane błędami cudzoziemców. Wybrane zagadnienia, w: A. Dąbrowska (red.), Wroctawska dyskusja o języku polskim jako obcym, Wrocław, s. 229-241.

Dąbrowska A., 2012, Składniowa konstrukcja dymorficzna jako błąd kompleksowy, „Poradnik Językowy", $\mathrm{nr} 6$.

Gębka-Wolak M., 2010, Problematyka szyku wyrazów w nauczaniu języka polskiego jako obcego, w: red. K. Taczyńska, K. Birecka (red.), Nowe perspektywy w nauczaniu języka polskiego jako obcego, Torun, s. 71-78.

Jodłowski S., 1976, Podstawy polskiej składni, Warszawa.

Rada Europy, Europejski system opisu ksztatcenia językowego: uczenie sie, nauczanie, ocenianie, Warszawa 2003.

Stasieczek-Górna M., 2011, Błędy szyku zdania popetniane przez cudzoziemców uczących sięjęzyka polskiego, „Acta Universitatis Lodziensis. Kształcenie Polonistyczne Cudzoziemców”, nr 18.

Uniwersalny stownik języka polskiego, 2003, pod red. S. Dubisza, Warszawa.

Zawilska D., 1997, O niektórych błędach szyku wyrazów w wypowiedzeniu pojedynczym we wspótczesnym język polskim, „Acta Universitatis Lodziensis. Kształcenie Polonistyczne Cudzoziemców", nr 9.

Edyta Wojtczak

\section{SYNTACTIC COMPETENCE AND ITS SHORTCOMINGS IN POLISH SPOKEN BY THE STUDENTS OF POLISH AS A FOREIGN LANGUAGE}

Keywords: teaching Polish as a foreign language, syntactic competence, syntactic error, spoken language.

Summary. The article discusses syntactic competence and its shortcomings in Polish spoken by the foreigners. The author presents spontaneous utterances of the students from Angola, and analyses these utterances from the point of syntactic correctness. The utterances have been collected during observations of Polish language classes at the School of Polish for Foreign Students at the University of Lodz. The comparison of correct utterances with incorrect ones shows which syntax issues were not problematic for the foreigners, and which aspects of Polish syntax caused some difficulty. 